\title{
Corrigendum: A succinct overview of virtual reality technology use in Alzheimer's disease
}

\author{
Rebeca I. García-Betances*, María Teresa Arredondo Waldmeyer, Giuseppe Fico and \\ María Fernanda Cabrera-Umpiérrez
}

Life Supporting Technologies (LifeSTech), ETSI Telecomunicaciones, Universidad Politécnica de Madrid, Madrid, Spain

Keywords: Alzheimer's disease, mild cognitive impairment, cognitive rehabilitation, virtual reality, virtual environments

\section{A corrigendum on}

A succinct overview of virtual reality technology use in Alzheimer's disease

by García-Betances, R. I., Arredondo Waldmeyer, M. T., Fico, G., and Cabrera-Umpiérrez, M. F. (2015). Front. Aging Neurosci. 7, 80. doi: 10.3389/fnagi.2015.00080

Due to a misunderstanding, the "last name" of the main author of reference: Giglioli et al., 2015, is a two-word name "Chicchi Giglioli" and not "Giglioli." Consequently, reference Giglioli et al., 2015 should read:

Chicchi Giglioli, I. A., Pallavicini, F., Pedroli, E., Serino, S., and Giuseppe Riva, G. (2015). Augmented reality: a brand new challenge for the assessment and treatment of psychological disorders, review article. Comput. Math. Methods Med. Article ID: 862942.

\section{OPEN ACCESS}

Edited and reviewed by: Valeria Manera, University of Nice Sophia Antipolis,

France

*Correspondence: Rebeca I. García-Betances rgarcia@/st.tfo.upm.es

Received: 20 November 2015 Accepted: 30 November 2015 Published: 14 December 2015

\section{Citation:}

García-Betances RI, Arredondo Waldmeyer MT, Fico G and Cabrera-Umpiérrez MF (2015) Corrigendum: A succinct overview of virtual reality technology use in Alzheimer's disease. Front. Aging Neurosci. 7:235. doi: 10.3389/fnagi.2015.00235
Conflict of Interest Statement: The authors declare that the research was conducted in the absence of any commercial or financial relationships that could be construed as a potential conflict of interest.

Copyright $\odot 2015$ García-Betances, Arredondo Waldmeyer, Fico and Cabrera-Umpiérrez. This is an open-access article distributed under the terms of the Creative Commons Attribution License (CC BY). The use, distribution or reproduction in other forums is permitted, provided the original author(s) or licensor are credited and that the original publication in this journal is cited, in accordance with accepted academic practice. No use, distribution or reproduction is permitted which does not comply with these terms. 